\title{
Correction to: Spatiotemporal expression profle of novel and known small RNAs throughout rice plant development focussing on seed tissues
}

\author{
Anikó Meijer ${ }^{1}$, Tim De Meyer ${ }^{2}$, Klaas Vandepoele $e^{3,4,5^{*+}}$ and Tina Kyndt ${ }^{1^{*+}}$
}

Correction to: BMC Genomics 23, 44 (2022)
https://doi.org/10.1186/s12864-021-08264-z

Following publication of the original article [1], a typographical error was reported in the 'Background' section of the article. The incorrect and corrected sentences are given below, with the correction highlighted in bold:

The incorrect sentence read:

Twenty-one nt siRNAs, on the other hand, mainly cause transcriptional repression through the plant-specific RNA-directed DNA methylation (RdDM) pathway, inducing de novo DNA methylation [8].

The corrected sentence is:

Twenty-four nt siRNAs, on the other hand, mainly cause transcriptional repression through the plant-specific RNA-directed DNA methylation (RdDM) pathway, inducing de novo DNA methylation [8].

The original article [1] has been corrected.

\section{Author details}

'Department of Biotechnology, Ghent University, Ghent, Belgium. '2Department of Data Analysis and Mathematical Modelling, Ghent University, Ghent, Belgium. ${ }^{3}$ Department of Plant Biotechnology and Bioinformatics, Ghent

The original article can be found online at https://doi.org/10.1186/s12864021-08264-z.

*Correspondence: Klaas.Vandepoele@psb.vib-ugent.be; Tina.Kyndt@UGent.be

${ }^{\dagger}$ Klaas Vandepoele and Tina Kyndt contributed equally to this work.

${ }^{1}$ Department of Biotechnology, Ghent University, Ghent, Belgium

${ }^{5}$ Bioinformatics Institute Ghent, Ghent University, Ghent, Belgium

Full list of author information is available at the end of the article

University, Ghent, Belgium. ${ }^{4}$ VIB Center for Plant Systems Biology, Ghent, Belgium. ${ }^{5}$ Bioinformatics Institute Ghent, Ghent University, Ghent, Belgium.

Published online: 16 February 2022

\section{Reference}

1. Meijer A, De Meyer T, Vandepoele K, et al. Spatiotemporal expression profile of novel and known small RNAs throughout rice plant development focussing on seed tissues. BMC Genomics. 2022;23:44. https://doi.org/10. 1186/s12864-021-08264-z.

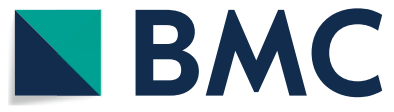

(c) The Author(s) 2022. Open Access This article is licensed under a Creative Commons Attribution 4.0 International License, which permits use, sharing, adaptation, distribution and reproduction in any medium or format, as long as you give appropriate credit to the original author(s) and the source, provide a link to the Creative Commons licence, and indicate if changes were made. The images or other third party material in this article are included in the article's Creative Commons licence, unless indicated otherwise in a credit line to the material. If material is not included in the article's Creative Commons licence and your intended use is not permitted by statutory regulation or exceeds the permitted use, you will need to obtain permission directly from the copyright holder. To view a copy of this licence, visit http://creativecommons.org/licenses/by/4.0/. The Creative Commons Public Domain Dedication waiver (http://creativeco mmons.org/publicdomain/zero/1.0/) applies to the data made available in this article, unless otherwise stated in a credit line to the data. 